\title{
A bölcsességfog és az occlusio szerepének vizsgálata a mandibulaangulus és -condylus töréseiben
}

\author{
Soós Balázs dr. ${ }^{1}$ - Janovics Kata dr. ${ }^{1}$ - Tóth Ákos dr. ${ }^{2}$ - Szalma József dr. ${ }^{1}$ \\ ${ }^{1}$ Pécsi Tudományegyetem, Általános Orvostudományi Kar, Klinikai Központ, \\ Fogászati és Szájsebészeti Klinika, Pécs \\ ${ }^{2}$ Pécsi Tudományegyetem, Természettudományi Kar, Sporttudományi és Testnevelési Intézet, Pécs
}

\begin{abstract}
Bevezetés és célkitüzés: Retrospektív keresztmetszeti vizsgálatunk célja az occlusiós megtámasztás és az alsó bölcsességfog szerepének vizsgálata volt az angulus- és condylustöréseknél.

Módszer és eredmények: Egyoldali, izolált angulus- vagy condylustörött betegeket vizsgáltunk. Az adatgyüjtés betegkartonok és panoráma-röntgenfelvételek segítségével történt. Vizsgálatunkban az elsődleges prediktor változó az occlusiós megtámasztás minősége, a másodlagos prediktor a bölcsességfog jelenléte vagy hiánya volt. A kimeneti változó a törés típusa, illetve az egyéb prediktorok a demográfiai adatok voltak. A prediktorok és a kimeneti változók közti összefüggéseket khi-négyzet-teszttel és logisztikus regressziós analízissel vizsgáltuk. Az angulustörött csoportot 43 (átlagéletkor: 29,9 $\pm 12,8$ év; 98,4\% férfi), míg a condylustörött csoportot 37 beteg (átlagéletkor: 46,8 $\pm 20,2$ év; $62,2 \%$ férfi) alkotta. Angulustörés esetén 81,4\%-ban, míg condylustörés esetén 51,3\%-ban láttunk kétoldali occlusiós megtámasztást $(\mathrm{p}<0,001)$. Kétoldali occlusiós megtámasztás esetén az angulustörés esélyhányadosa 4,2 volt $(\mathrm{p}<0,006)$. Az angulustörések 86\%-ában, a condylustörések 43,2\%-ában volt jelen bölcsességfog a törés oldalán $(\mathrm{p}<0,001)$. Azonos oldali bölcsességfog jelenléte esetén az angulustörés esélye a 8,1 -szeresére emelkedett $(\mathrm{p}<0,001)$. Amennyiben kétoldali occlusiós megtámasztás és törésoldali bölcsességfog is jelen volt, az angulustörés esélye a 15,9-szeresére nőtt $(\mathrm{p}<0,001)$.

Következtetés: Az occlusiós megtámasztás és a bölcsességfog együttes és külön-külön való jelenléte is egyértelmúen fokozta az angulustörés, és csökkentette a condylustörés rizikóját, míg hiányuk a condylustörés rizikóját fokozta, és az angulustörés esélyét csökkentette.
\end{abstract}

Orv Hetil. 2020; 161(28): 1166-1174.

Kulcsszavak: occlusiós megtámasztás, bölcsességfog, mandibulatörés, angulustörés, condylustörés

\section{The role of occlusal support and lower third molars in mandibular angle and condylar fractures}

Introduction and aim: The aim of our study was to investigate the influence of the occlusal support, and mandibular third molars on mandibular angle and condylar fractures.

Method and results: Patients with unilateral and isolated angle or condylar fractures were included in this retrospective, cross-sectional study. Data was collected from patient records and panoramic $\mathrm{x}$-rays. The predictor variables included the type of occlusal support and the presence or absence of third molars. The outcome variable was angle or condylar fracture, while other predictor variables included demographic factors. Bivariate $\left(\chi^{2}\right.$ test) and logistic regression analyses were conducted to investigate the associations between variables and the outcome. 43 angle (mean age: $29.9 \pm 12.8$ years; $98.4 \%$ male) and 37 condylar (mean age: $46.8 \pm 20.2$ years; $62.2 \%$ male) fracture cases were included in this study. Bilateral occlusal support was present in $81.4 \%$ of angle fracture group and in $51.3 \%$ of condylar fracture group $(\mathrm{p}<0.001)$. In the case of bilateral occlusal support, an odds ratio $(\mathrm{OR})$ of 4.2 was found for angle fractures $(\mathrm{p}<0.006)$. A third molar was present in $86 \%$ of the angle fracture group and in $43.2 \%$ of the condylar fracture group $(\mathrm{p}<0.001)$. The presence of a third molar exhibited an odds ratio of 8.1 for the angle fractures $(p<0.001)$. When bilateral occlusal support and third molar were present simultaneously, the risk was 15.9 times higher for an angle fracture $(\mathrm{p}<0.001)$. 
Conclusion: The presence of occlusal support and/or third molars was significantly associated with angle fractures, however, the absence of occlusal support and/or third molars significantly correlated with condylar fractures.

Keywords: occlusal support, third molar, mandible fracture, angle fracture, condylar fracture

Soós B, Janovics K, Tóth Á, Szalma J. [The role of occlusal support and lower third molars in mandibular angle and condylar fractures]. Orv Hetil. 2020; 161(28): 1166-1174.

(Beérkezett: 2020. március 11.; elfogadva: 2020. március 31.)

\section{Rövidítések}

$\mathrm{CI}=$ konfidenciaintervallum; $\mathrm{OR}=$ (odds ratio) esélyhányados; PG = Pell-Gregory; PTE KK = Pécsi Tudományegyetem, Klinikai Központ

A mandibulatörés az orrcsonttörés után a leggyakrabban diagnosztizált csonttörés a maxillofacialis területen. Szakirodalmi adatok alapján a mandibulatörések teszik ki a teljes maxillofacialis csontsérülési spektrum mintegy 36-76\%-át $[1,2]$. Ez a magas incidencia a mandibula prominens, sérüléseknek kitett elhelyezkedésével, anatómiai felépítésével, valamint limitált csontos megtámasztásával és nagyfokú mobilitásával lehet kapcsolatban [3]. A mandibula törései között a condylustörés a leggyakoribb. Ez a régió az esetek 25-52\%-ában érintett [2,4]. A mandibula egyéb, törések által érintett területei a következők lehetnek: a symphisis-, illetve parasymphisis-tájék (kb. 45\%), a corpus (kb. 25,5\%), valamint az angulustájék (kb. 16,5\%) [2]. Bizonyos szerzők az angulus érintettségét mintegy 25-33\%-nak találták [5, 6].

A mandibulatörés helyét számos faktor befolyásolhatja; ezeket intrinszik és extrinszik csoportba lehet sorolni. A törés helyét befolyásoló intrinszik faktorok között megemlítendő a mandibula alakja, a csontrétegek denzitása és vastagsága, a csontot érintő patológiás elváltozások jelenléte, a csontot körülvevő izomzat jellemzői, a fogak megléte vagy hiánya és ezáltal az occlusiós megtámasztás minősége vagy annak hiánya. Az extrinszik tényezők közé tartozik a mandibulát érő erőbehatás intenzitása, helye és iránya, amit nagymértékben meghatároz a törés etiológiája $[7,8]$. A törés etiológiai faktorai lehetnek közlekedési balesetek, erőszakos cselekmények, esések, iatrogén ártalmak, kerékpározás és különböző sporttevékenységek [6, 9, 10]. Férfiak körében lényegesen gyakoribb a mandibulatörés előfordulása. Ez a férfinem számos, a törés etiológiai faktoraként szereplő tevékenységben (például verekedés, közlekedés, sport) való kimagasló részvételének lehet köszönhető. Szakirodalmi adatok alapján lényeges korkülönbség nem látható az angulustörést elszenvedő $(24,5-37,95$ év) és a condylustörött betegek (26,35-36,9 év) között [10-12].

Ahogy korábban említettük, a condylustájék törésének a legmagasabb az incidenciája. Ez a tény azzal magyarázható, hogy a processus condylaris az állkapocs leggyen- gébb területe, köszönhetően a mandibula egyéb területeihez képest alacsonyabb denzitásának, illetve a mechanikai erőkkel szembeni ellenállás szempontjából előnytelen anatómiai felépítésének [7, 13, 14].

Számos korábbi tanulmány beszámolt az alsó bölcsességfogak jelenlétének a mandibulatörés lokalizációját módosító hatásáról [7, 10-12, 15-17]. Az alsó bölcsességfog jelenléte a mandibulaszögletet gyengíti, és növeli a törési rizikóját [10, 17-20]. Armond és mtsai 2017-es metaanalízisükben konkludálták, hogy az alsó bölcsességfog jelenléte 3,27-szeres rizikót jelent az angulustörésre $[10,12]$. Ez magyarázható a felületesen elhelyezkedő bölcsességfog által megszakított corticalis állománnyal vagy a csontban mélyen elhelyezkedő, teljesen impaktált bölcsességfog által a csontszövet kárára elfoglalt területtel $[10,11,15,16]$. Másfelől sok korábbi publikáció az alsó bölcsességfogak jelenlétének condylustörés-rizikót csökkentő hatását konkludálta [12, 1720]. Reitzik és mtsai experimentális vizsgálatukban majommandibulákon kimutatták, hogy előtörésükben visszamaradt bölcsességfogak jelenlétében már 60\%-os erőbehatás elég volt az állkapocs eltöréséhez, szemben a kontrollcsoporttal, amely teljesen előtört bölcsességfogakkal bíró alsó állcsontokból tevődött össze [21]. Bezerra és mtsai 2013-ban publikált véges elemes analízisükben kimutatták, hogy a mandibulaszöglet törékenységét növeli az alsó bölcsességfog megléte. Ha azonban hiányzik a bölcsességfog, az állkapcsot érő erők a processus condylaris lateralis és hátsó részére tevődnek át, ott koncentrálódnak, így fokozva a fejecsrégió sérülékenységét [16]. Az angulus- és condylustörések incidenciája függ a bölcsességfogak elhelyezkedésétől is. A sagittalis síkban a bölcsességfogak helyzetét a Pell-Gregory (PG)osztályozással szokás leírni. Az impakció sagittalis mértékét sorrendben az I., II., III., illetve vertikális mélységét az A, B, C osztályok jelölik [22]. A PG II. (= a bölcsességfog a ramus által részben fedve van) és a PG $\mathrm{B}$ (= a bölcsességfog legkoronálisabb pontja a rágósík és a szomszédos fog zománc-cement junkciója között van) osztályba sorolt bölcsességfogakat az angulustörés szempontjából rizikótényezőknek tekintik, a condylustörés esélyét viszont csökkentik [10, 12, 23]. Az olyan condylustörések esetén, amikor jelen van a bölcsességfog, az leggyakrabban a PG I/A osztályba sorolható (= teljesen előtört, fogsorba illeszkedő fog) [12]. Érdekesség, hogy 
a bölcsességfognak a szomszédos foggal bezárt szöge (Winter szerinti osztály) és a condylus-, illetve angulustörések között a legtöbben nem találtak statisztikailag szignifikáns összefüggést $[10,12,24]$.

A törések ellátásának egyik, régóta sikerrel alkalmazott módszere a mưtéti feltárásban történő törtvégreponálás és lemezes osteosynthesis elvégzése [25]. Néhány esetben a törésvonalban elhelyezkedő bölcsességfog zavarhatja a korrekt törésreponálást, így eltávolítása elkerülhetetlen a sikeres kezeléshez [26, 27]. A condylustörés kezelése az anguluséhoz képest sokkal nagyobb kihívást jelent, valamint súlyosabb szövődményeket rejt a nehéz megközelíthetőség, a rossz rálátás, illetve a mütéti terület közelében futó nagyobb ér- és idegképletek miatt [3, 28, 29].

Az előtörésében visszamaradt bölcsességfog jelenléte tehát fokozhatja az angulustörés rizikóját, ugyanakkor csökkentheti a condylustörés valószínúségét $[10,12]$. Hiányzó alsó bölcsességfog esetén azonban az angulustájék a töréssel szemben ellenállóbb lesz, így fokozódik a condylustörés rizikója [30]. Ezért a panasz- és tünetmentes, egészséges, de előtörésükben visszamaradt bölcsességfogak profilaktikus eltávolításának indikációja kérdéseket vet fel; ráadásul földrajzi eltérések is befolyásolhatják az állkapocstörések etiológiai tényezőit [31, 32]. Megjegyzendő, hogy a témában publikált metaanalízisek is eltérő eredményeket közölnek, további nagyobb esetszámú vizsgálatok szükségességét jelezve $[29,33]$.

A bölcsességfogak mellett az occlusiós megtámasztás minőségének is fontos szerepe lehet a mandibulatörés kialakulásában [34]. Legjobb tudomásunk szerint kevés tanulmány foglalkozik az occlusiós megtámasztás szerepével angulus- és condylustörések esetén, valamint csak egy publikáció született, amely az occlusiós megtámasztás szerepét vizsgálja a töréskezelést követő posztoperatív szövődmények incidenciája tekintetében [34-37].

Jelen vizsgálatunk az angulus- és condylustörések esetén egyrészt az occlusiós megtámasztás, másrészt a bölcsességfogak szerepének vizsgálatát tûzte ki célul. A vizsgálat abból a feltételezésből indult ki, hogy az alsó bölcsességfogak gyengítik a mandibula angulusrégióját, ezért angulustörések gyakrabban láthatók alsó bölcsességfog jelenlétében; továbbá abból, hogy az angulustájék bölcsességfog jelenléte nélkül kevésbé sérülékeny, ezért ilyen esetben fokozott a condylustörés rizikója. További feltevésünk szerint amennyiben a molaris régióban található legalább egy occlusiós érintkezés, akkor az azonos oldalon nó az angulustörés kockázata, ha viszont nincs occlusiós érintkezés a molaris régióban, a condylus területe válik sérülékenyebbé.

\section{Módszer}

A jelen tanulmány keresztmetszeti, retrospektív vizsgálaton alapult (az etikai engedély száma: 8094 - PTE 2019.). A vizsgálatban a 2005. január és 2019. május között a Pécsi Tudományegyetem Általános Orvostudományi Karának Fogászati és Szájsebészeti Klinikáján mandibulatöréssel jelentkező betegek vettek részt. A jelen vizsgálatban csak egyoldali, izolált angulus- vagy condylustörést szenvedő betegek vettek részt, tehát a beválogatott betegek csak egy törést szenvedtek, amely vagy az angulust, vagy a condylust érintette. Az alább felsorolt kritériumok közül bármelyik fennállása az alany vizsgálatból való kizárását eredményezte: i) 15 évnél fiatalabb életkor, ii) panfacialis törés, iii) hiányos dokumentáció (például az occlusio minőségérôl hiányzó vagy nem egyértelmú adat) és iv) korlátozott diagnosztikai értékű röntgenfelvételek (például jelentősen diszlokált alsó bölcsességfog vagy súlyos pozicionálási hiba) vagy v) bilateralis (angulus vagy condylus) vagy contralateralis törések jelenléte.

\section{Vizsgált változók}

Az elsödleges prediktor változó az occlusiós megtámasztás jelenléte vagy hiánya volt. Az occlusiós megtámasztás alapján az eseteket öt kategóriába soroltuk Hasegawa és mtsai szerint [34]. Az A csoportba a teljes fogatlan esetek kerültek, a B csoportban csak a törés oldalán volt a molaris régióban legalább egy occlusiós érintkezés, a C csoportban csak az ellenoldalon volt molaris occlusiós érintkezés, a D csoportban mindkét oldalon találtunk a molaris területen legalább egy occlusiós érintkezést; az E csoportba kerültek az egyéb esetek, amelyeknél nem volt molaris területi occlusiós érintkezés, de nem állt fenn teljes fogatlanság sem.

A másodlagos prediktor változó az alsó bölcsességfog hiánya vagy megléte volt. Az eseteket ez alapján négy kategóriába soroltuk. Az 1. csoportban csak a töréssel azonos oldalon volt bölcsességfog, a 2. csoportban csak a töréssel ellenoldali bölcsességfog volt jelen, a 3. csoportban mindkét oldalon, míg a 4 . csoportban egyik oldalon sem volt bölcsességfog. A bölcsességfogak impakciós statusát és szögelhajlását a jelen tanulmányban nem vizsgáltuk.

A kimeneti változó a törés lokalizációja (angulus vagy condylus) volt. Kelly és Harrigan definíciója alapján condylustörést diagnosztizáltunk, amennyiben a processus condylarist érintő törésvonal az incisura mandibulae szintjében vagy fölötte húzódott. Angulustörés volt a diagnózis, ha a törésvonal a második molaris fog distalis területe és a mandibula alsó és hátsó éleinek találkozási pontja között helyezkedett el [38].

Az egyéb prediktor változók közé soroltuk a betegek korát, nemét és az etiológiai tényezőket (közlekedési baleset, erőszak, sportbaleset, esés, háztartási baleset).

\section{Adatgyüjtés és képalkotó elemzés}

Az adatgyújtés az eMedsolution orvosi adminisztrációs szoftver (T-Systems Magyarország, Budapest, Magyarország), papíralapú betegkartonok, illetve panoráma- 
röntgenfelvételek elemzésével történt. A bölcsességfogak jelenlétét vagy hiányát panoráma-röntgenfelvételek alapján regisztráltuk. A panorámafelvételek digitális technológiával készültek (PaX-400C 10,42 vonalpár/ $\mathrm{mm}$ maximális felbontóképességgel; Vatech, Gyeonggido, Dél-Korea). A digitális felvételek kiértékelése EasyDent szoftver (Vatech) segítségével történt. A digitális panoráma-röntgenfelvételek elemzéséhez a röntgen képnézegető program beépített képmanipulációs eszközeit alkalmazhattuk (nagyítás, kontraszt, fényerő, élesség, inverz színmegjelenítés) [39]. Az occlusiós megtámasztással kapcsolatos adatfelvétel az egyértelmú esetekben (például teljes fogatlanság, mindkét oldalon legalább az alsó vagy a felső állcsontot érintő teljes molaris foghiány - ilyen feltételek 22 esetben teljesültek) panoráma-röntgenfelvételek segítségével, a kérdéses esetekben a klinikai vizsgálatkor a betegkartonra rögzített adatok alapján történt.

\section{Statisztikai módszerek}

A statisztikai analízishez az SPSS program 25.0 verzióját használtuk (IBM, Armonk, NY, Amerikai Egyesült Államok). A kapcsolatot a prediktor változók (az occlusio minősége, bölcsességfog hiánya vagy jelenléte) és a kimeneti változók (angulus versus condylus törése) között Pearson-féle khi-négyzet-próbával vizsgáltuk. Az angulustörés- és a condylustörés-csoportok átlagéletkorának összehasonlítását Mann-Whitney-féle kétmintás rangöszszegteszttel végeztük. Az angulustörésre esélyhányadost (odds ratio: OR) számoltunk, és logisztikus regressziós analízist végeztünk az angulus- versus condylustörések etiológiájával kapcsolatos szignifikáns faktorok megállapítására. Szignifikanciaszintnek a $\mathrm{p} \leq 0,05$ értéket tekintettük.

\section{Eredmények}

A vizsgált időszakban a PTE KK Fogászati és Szájsebészeti Klinikáján 740, mandibulatörést szenvedett beteget kezeltünk. A beválogatási és kizárási kritériumok alkalmazása után 660 eset kizárásra került. A jelen vizsgálat 43 angulustörést és 37 condylustörést, tehát összesen 80 esetet dolgoz fel 80 beteg körében.

$\mathrm{Az}$ angulustörések 37,2\%-a, míg a condylustörések $43,2 \%$-a a jobb oldalt érintette. Az angulus- és condylustörés kórokai a következők voltak: testi erőszak 35 esetben $(43,8 \%)$, esés 29 esetben $(36,3 \%)$, közlekedési baleset 4 esetben ( $5 \%)$, háztartási baleset 2 esetben $(2,5 \%)$, sportbaleset 6 esetben $(7,5 \%)$ és egyéb ok 4 esetben (5\%). Az angulustörések (43 eset) kóroki tényezői a következők voltak: testi erőszak 26 esetben $(60,5 \%)$, esés 8 esetben $(18,6 \%)$, közlekedési baleset 2 esetben $(4,7 \%)$, háztartási baleset 1 esetben $(2,3 \%)$, sportbaleset 4 esetben $(9,3 \%)$ és egyéb 2 esetben $(4,7 \%)$. A condylustörés (37 eset) kórokai a következők voltak: testi erőszak 9 esetben $(24,3 \%)$, esés 21 esetben $(56,8 \%)$, közlekedési

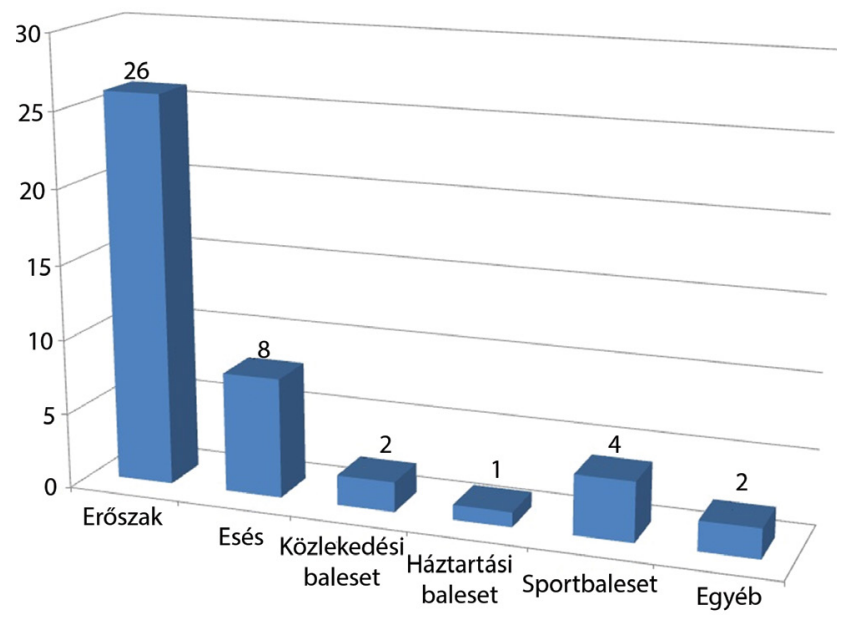

1. ábra $\quad$ Az angulustörés etiológiai tényezőinek megoszlása. Szembetűnő az erőszakos cselekedetek dominanciája, amit az esések követnek

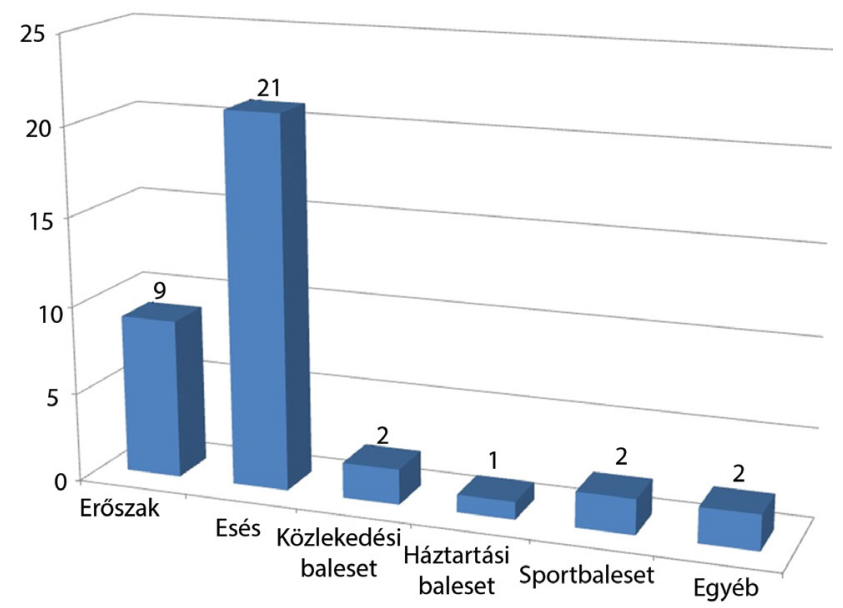

2. ábra

A condylustörés etiológiai tényezőinek megoszlása. Jól látható az esés vezető szerepe, amit a testi erőszak követ

baleset 2 esetben $(5,4 \%)$, háztartási baleset 1 esetben $(2,7 \%)$, sportbaleset 2 esetben $(5,4 \%)$ és egyéb ok szintén 2 esetben $(5,4 \%)$ (l.és 2. ábra).

A betegek átlagéletkora az angulustörés-csoportban $29,9 \pm 12,8(17-74)$ év, a condylustörés-csoportban $46,8 \pm 20,2$ (17-89) év volt. A két csoport életkora között szignifikáns eltérést találtunk $(\mathrm{p}<0,001$, MannWhitney-teszt). A férfi/nő arány 38/5 (98,4\% férfidominancia) volt az angulustörés-csoportban, míg 23/14 (62,2\% férfidominancia) a condylustöröttek körében (OR: 0,$2 ; 95 \%$ konfidenciaintervallum [CI]: $0,07-0,68$; $\mathrm{p}=0,009$, khi-négyzet-teszt) (1. táblázat). A condylustöröttek csoportjában szignifikánsan több nőbeteget találtunk.

A 43 esetet számláló angulustörés-csoportból 35 esetben $(81,4 \%)$, míg a 37 condylustörött betegek között 19 esetben $(51,3 \%)$ volt jelen mindkét oldali molaris régióban legalább egy occlusiós érintkezés. Kizárólag a töréssel azonos oldali molaris occlusiót angulustöréssel asszo- 


\begin{tabular}{|c|c|c|c|c|c|c|}
\hline \multirow[t]{2}{*}{ A vizsgálat változói } & \multirow{2}{*}{$\begin{array}{l}\text { Angulustörés } \\
\quad(\mathrm{n}=43)\end{array}$} & \multirow{2}{*}{$\begin{array}{l}\text { Condylustörés } \\
\quad(\mathrm{n}=37)\end{array}$} & \multirow[t]{2}{*}{ Esélyhányados } & \multicolumn{2}{|c|}{ Konfidenciaintervallum } & \multirow[t]{2}{*}{ p-érték* } \\
\hline & & & & Alsó érték & Felső érték & \\
\hline \multicolumn{7}{|l|}{ Életkor } \\
\hline Átlag \pm szórás & $29,9 \pm 12,8$ & $46,8 \pm 20,2$ & & & & $<0,001^{* *}$ \\
\hline Tartomány & $17-74$ & $17-89$ & & & & \\
\hline Nem (férfi/nő) & $38 / 5$ & $23 / 14$ & 0,2 & 0,07 & 0,68 & 0,009 \\
\hline Bölcsességfog jelen van & $37(86)$ & $16(43,2)$ & 8,1 & 2,75 & 23,84 & $<0,001$ \\
\hline Kétoldali molaris occlusio van & $35(81,4)$ & $19(51,3)$ & 4,2 & 1,50 & 11,30 & 0,006 \\
\hline $\begin{array}{l}\text { Kétoldali moláris okklúzió és ipszi-/bilateralis } \\
\text { bölcsességfog van }\end{array}$ & $34(79,1)$ & $12(32,4)$ & 15,9 & 4,43 & 56,81 & $<0,001$ \\
\hline Fogatlanság & $1(2,3)$ & $3(8,1)$ & 0,3 & 0,03 & 2,71 & 0,15 \\
\hline Nincs molaris occlusio, és nincs teljes fogatlanság & $5(11,6)$ & $13(35,1)$ & 0,2 & 0,08 & 0,75 & 0,014 \\
\hline
\end{tabular}

*Khi-négyzet-teszt; * *Mann-Whitney-teszt; a zárójelben \%-os értékek szerepelnek

ciáltan nem láttunk, míg condylustörés esetén ez az esetszám $2(5,4 \%)$ volt. Csak a töréssel ellenoldali occlusiós megtámasztást az angulustörés-csoportban 2 esetben tapasztaltunk (4,7\%), míg a condylustöröttek csoportjában egyszer sem láttunk ilyet. Az angulustöréscsoportból $1(2,3 \%)$ beteg esetén, a condylustörés-csoportból 3 esetben $(8,1 \%)$ volt teljes fogatlanság a diagnózis. Az 'egyéb' kategóriába (molaris occlusiós megtámasztás hiánya nem teljes fogatlanság esetén) tartozott az angulustöröttek csoportjából 5 eset $(11,6)$, míg a condylustörés-csoportból 13 eset $(35,1 \%)$. Kétoldali molaris occlusio esetén szignifikánsan többször találtunk angulustörést, mint egyoldali molaris occlusiós vagy molaris occlusiós megtámasztás nélküli esetekben (OR: 4,2; 95\% CI: 1,50-11,30; p = 0,006, khi-négyzetteszt). Teljes fogatlanság a condylustörés-csoportban fordult elő többször, de ez nem volt szignifikáns (OR: 0,3; 95\% CI: 0,03-2,71; p = 0,15, khi-négyzet-teszt). Az egyéb típusú occlusiós megtámasztások csoportjában szignifikánsan gyakrabban találtunk condylustörést, mint angulustörést (OR: 0,2; 95\% CI: 0,08-0,75; p = 0,014, khi-négyzet-teszt) (1. táblázat).

A 43, angulustörést szenvedett beteg körében 37 esetben $(86 \%)$, míg a 37 condylustörött beteg között 16 esetben $(43,2 \%)$ volt jelen a töréssel ipsilateralis elhelyezkedésű bölcsességfog. Az angulustöröttek körében a fennmaradó 6 esetből 2 esetben (4,7\%) láttunk ellenoldali bölcsességfogat, míg 4 esetben $(9,3 \%)$ bölcsességfoghiányt. A condylustöröttek csoportjában a maradék 21 esetből 4 esetben $(10,8 \%)$ csak ellenoldali bölcsességfog volt jelen, míg 17 esetben $(35,1 \%)$ hiányoztak a bölcsességfogak. Az alsó bölcsességfog jelenléte és az angulustörés kialakulása között szignifikáns összefüggést mutattunk ki (OR: 8,1; 95\% CI: 2,75-23,84; p<0,001, khi-négyzet-teszt) (1. táblázat). A bölcsességfog hiánya szignifikánsan asszociálódott a condylustöréssel $(\mathrm{p}<0,001)$. Vizsgálatunk kétoldali molaris occlusiós megtámasztás esetén, amennyiben jelen volt törésoldali bölcsességfog, az angulustöréssel kiemelkedően szignifi- káns kapcsolatot igazolt (OR: 15,9; 95\% CI: 4,43-56,81; $\mathrm{p}<0,001$, khi-négyzet-teszt).

A bölcsességfogak és az occlusiós paraméterek, illetve a demográfiai változók együttes hatását logisztikus regressziós analízissel is vizsgáltuk, azonban - feltehetően az alacsony esetszámok miatt - szignifikáns eredményeket a regressziós modell nem eredményezett.

\section{Megbeszélés}

Vizsgálatunk célja a mandibula törésmintázata és az occlusio minősége, illetve az alsó bölcsességfogak jelenléte vagy hiánya közti összefüggések elemzése volt. Hipotézisünk szerint a molaris régióban lévő occlusiós megtámasztás csökkenti a condylustájék törésének valószínűségét, ugyanakkor fokozza az angulustörés rizikóját. Emellett feltételeztük, hogy bölcsességfog jelenlétében gyengül az állkapocs angularis területe, így jelenléte esetén nő az angulustörés rizikója, ugyanakkor hiánya növeli a condylustörés rizikóját.

A mandibula nemcsak az egyéb maxillofacialis csontokkal összevetve, de a teljes csontozatot tekintve is nagyon gyakran szenved törést [15]. Ellis és mtsai 4711, maxillofacialis törést szenvedő betegen végzett vizsgálatukban 2137 betegnél $(45,4 \%)$ legalább egy mandibulatörést találtak [28]. Számos korábbi tanulmány elemezte az állkapocstörés lokalizációja és a bölcsességfog jelenléte, illetve impakciós statusa közti kapcsolatot [7, 10-12, 15-17]. Az állkapocstörés helyét extrinszik (a traumás eróhatással kapcsolatos) és intrinszik (a csonttal, a lágyrésszel, valamint az occlusióval kapcsolatos) tényezők befolyásolhatják [7, 15]. Nagy intenzitású trauma (például közlekedési baleset) a leggyakrabban az erőbehatás helyén okoz törést. Alacsony intenzitású trauma (testi erőszak, esés, sportbaleset) esetén az erő áttevődhet az erőbehatás helyétől távolabb eső régiókra is, így elérheti az eredendően gyengébb pontokat, ahol a koncentrálódó erők törést okozhatnak [13]. Az állkapocs eredendő- 
en leggyengébb területe általában a processus condylaris [14]. Vizsgálatunkban az angulustöröttek csoportjában a fó kiváltó ok a testi erôszak volt, azt követte az esés, majd a sportbaleset. A condylustörés-csoport leggyakoribb etiológiai tényezője az esés volt, amit a testi erőszak követett. Egyes, Szerbiában, Németországban, illetve Japánban végzett vizsgálatok hasonló eredményt találtak [18, 19, 40]. Eredményeink azonban eltértek számos, más országban (Brazília, India, Irán) végzett vizsgálatok eredményeitől, melyek a közlekedési baleset dominanciájáról számoltak be [20, 33, 41, 42].

Máig sincs egységes szakirodalmi álláspont abban a tekintetben, hogy az állkapocsszöglet töréssel szembeni ellenállásáért a tájékon lévő csont corticalis rétegének jellemzői (vastagság, denzitás, folytonosság) vagy inkább a régióban lévő csont abszolút mennyisége felelős. Korábbi vizsgálatok biomechanikai modellje alapján elmondható, hogy a rágóizmok és az occlusio által kifejtett erő az angulusrégió felső határán egy tenziós zónát (amely egybeesik a linea obliqua externával), míg alsó határán egy kompressziós zónát alakít ki. A csonttörés általában a tenziós erőknek kitett területekről indul ki. Amennyiben itt a corticalis csont folytonossága megszakad, például egy ott lévő, részlegesen impaktált bölcsességfog által, a tenziós zóna töréssel szembeni ellenállása nagyban csökken, így fokozva az angulustörés kockázatát [15, 16]. Ha viszont nincs impaktált bölcsességfog (teljesen előtört bölcsességfog vagy bölcsességfog hiánya esetén), a tenziós zóna mechanikai stresszel szembeni ellenállása fokozódik, és a töréshez szükséges küszöböt el nem érő nagyságú erók elvezetődhetnek, és koncentrálódhatnak a processus condylaris hátulsó és lateralis területén, így fokozva a condylustörés kialakulásának valószínüségét [7, 15, 16]. Ezek alapján számos kutató egyetért abban, hogy a bölcsességfog jelenléte és pozíciója befolyásolhatja a törés lokalizációját [7, 10-12, 15-17]. Az előzőek- ben leírtakkal szemben a Reitzik és mtsai által közölt experimentális vizsgálat alapján Lee és Dodson feltételezték, hogy minél nagyobb a bölcsességfogak által elfoglalt terület a csonton belül, annál magasabb lehet a törés rizikója az angulusrégióban $[7,21]$. Feltevésüket azonban nem tudták bizonyítani [7]. Safdar és mtsai feltételezték, hogy a mélyebben impaktált alsó bölcsességfog magasabb rizikót jelenthet angulustörésre, mint a felületesen elhelyezkedő, ám erre nem találtak meggyőző bizonyítékot [11].

A jelen vizsgálatban az előtörésében visszamaradt alsó bölcsességfog mind az angulus-, mind a condylustörések esetén rizikót módosító tényező volt. Vizsgálatunk ezen pontja összhangban van számos, korábbi vizsgálat eredményeivel, melyek szerint az impaktált bölcsességfog jelenléte növelheti az angulustörés rizikóját, és csökkentheti a condylustörés kialakulásának valószínüségét [17-20]. A bölcsességfog impakciós statusa szintén fontos tényező $[10,12,43,44]$. Az előző vizsgálatokkal ellentétben Iida és mtsai [18], valamint Hasegawa és $m$ tsai [34] nem találtak összefüggést az angulustörés és a bölcsességfog impakciós statusa között. Ruela és mtsai szerint a rendelkezésre álló szakirodalmi adatok alapján nem vonható le egyértelmű konklúzió abban a tekintetben, hogy a bölcsességfog jelenléte vagy impakciójának szintje játszik-e meghatározóbb szerepet az angulustörés rizikójának módosításában [45]. Jelen vizsgálatunk során az impakciós statusra külön nem tértünk ki, mivel azt egy korábbi közleményünkben kiterjedtebb esetszámmal már vizsgáltuk [17]. A jelen vizsgálat a bölcsességfogak jelenléte és az angulustörés kialakulása között szignifikáns összefüggést igazolt, ami összhangban van más kutatók eredményeivel [7, 10, 43, 46] (3. ábra).

Világszerte az egyik leggyakrabban elvégzett szájsebészeti beavatkozás az impaktált alsó bölcsességfogak eltávolítása $[47,48]$. A tünetmentes, egészséges, előtöré-

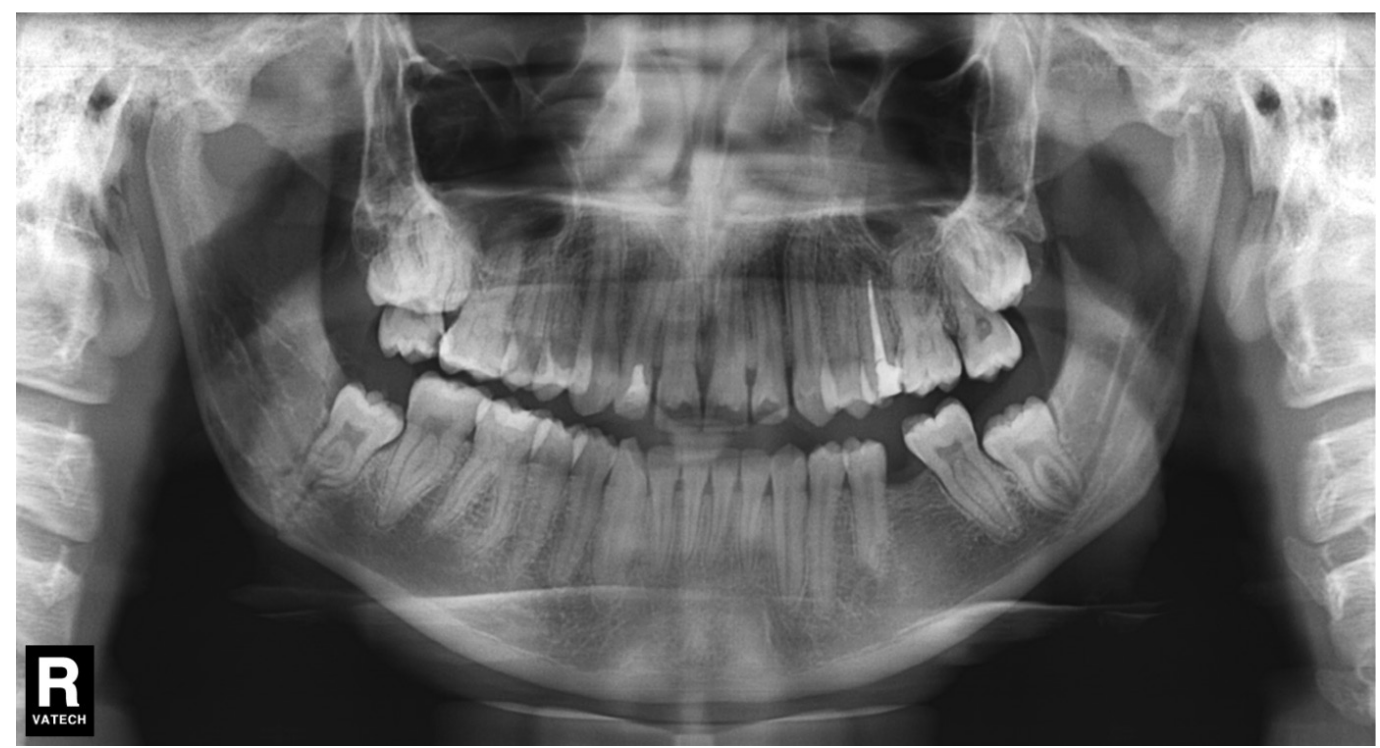




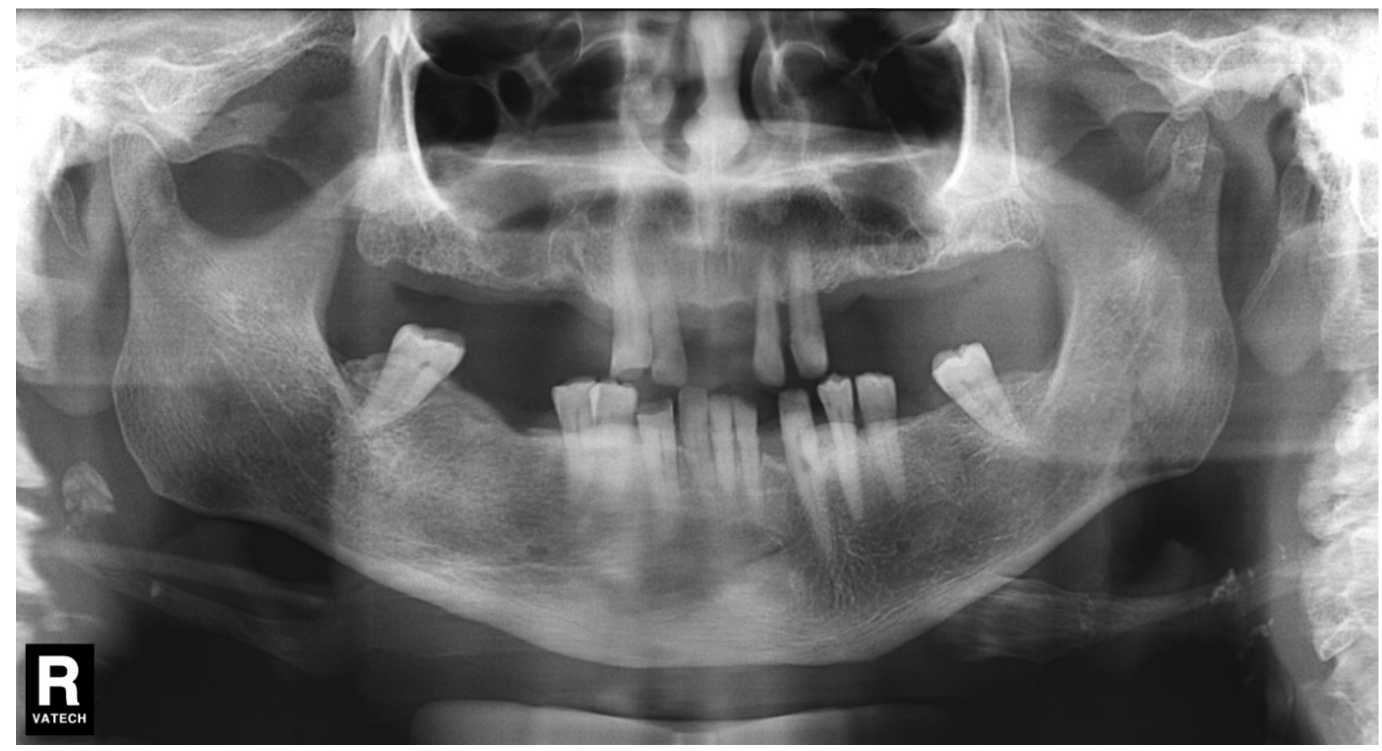

4. ábra

A panoráma-röntgenfelvételen bal oldali condylustörés látható 'cask front’ területi occlusiós érintkezésekkel és ipsilateralis bölcsességfoghiánnyal aszszociáltan

sében visszamaradt alsó bölcsességfogak profilaktikus eltávolításának oka a potenciálisan kifejlődő patológiás elváltozások prevenciója lehet [31]. Antic és mtsai nem javasolják az angulustörés prevenciója céljából az impaktált alsó bölcsességfogak eltávolítását [49]. Iida és mtsai szerint fiatal sportolók alsó bölcsességfogainak eltávolítása csökkenti az angulustörés, ugyanakkor fokozza a condylustörés kockázatát, ami a mandibulatörések közül súlyosabb szövődményekkel járhat [18]. További vizsgálatok szintén kimutatták, hogy a bölcsességfogak profilaktikus eltávolítása az angulusrégió posztoperatív megerősödését eredményezi, így fokozva a komolyabb lehetséges szövődményekkel járó condylustörés kockázatát $[20,29,42]$. Van, aki kritikával illeti a profilaktikus bölcsességfog-eltávolításnak a fentiekben leírt relatív kontraindikációját [33]. Vizsgálatunkban a bölcsességfoghiány szignifikánsan összefüggött a condylustörésekkel (4. ábra). Ez megegyezik számos korábbi kutatás eredményével $[12,17,20,40,43]$. Az idegsérülés szempontjából magas rizikójú bölcsességfog-eltávolítás alternatívája lehet a coronectomia elvégzése [50]. Egyelőre nincs releváns szakirodalmi adat, hogy a coronectomia kivitelezése hogyan befolyásolja a mandibula törésmintázatát.

Jelen vizsgálatunk kimutatta, hogy az occlusiós megtámasztás a molaris régióban szignifikánsan növeli az angulus-, míg ugyancsak szignifikánsan csökkenti a condylustörés kockázatát. Ugyanakkor az occlusiós megtámasztás hiánya fokozza a condylustörés valószínüségét, és csökkenti az angulustörés rizikóját. Ez összevethető a szakirodalomban fellelhető korlátozott számú forrás adataival, miszerint a distalis területen meglévő occlusio csökkentheti a condylustájék törésének rizikóját, és fokozhatja az angulustörés valószínúségét [34-36] (3. és 4. ábra). Ez azzal magyarázható, hogy az állkapoccsal kö- zölt erố egy része a molaris régióban occlusióba kerülő fogak által elnyelődik, így kevesebb erő jut el a processus condylaris területére. Ezt támaszthatja alá az a megfigyelés is, hogy gyakran észlelhető condylustöréssel ipsilateralis molaris fogállományi sérülés.

Vizsgálatunkban az angulus- és condylustöröttek csoportjának átlagéletkora összevethető volt a szakirodalmi adatokkal. Számos korábbi közleményhez hasonlóan, jelen vizsgálatunkban a condylustörést szenvedett csoport átlagéletkorát szignifikánsan magasabbnak találtuk, az angulustöröttek csoportjának átlagéletkorával összevetve [18, 20, 34, 40]. Egy korábbi tanulmány szerint a leggyakrabban tinédzserek, illetve húsz- és harmincéves betegek szenvednek angulustörést, míg a condylustörés a harminc és ötven év közötti populációban a leggyakoribb [42]. Egyes tanulmányok a kort nem találták szignifikáns faktornak a törésmintázat alakulásában [19, 33].

$\mathrm{Az}$ angulustörés tekintetében jelentős férfidominancia látható, mint ahogy számos korábbi vizsgálatban is [14, 18-20, 33, 34, 40]. A férfiak gyakrabban vesznek részt erőszakos cselekedetekben, mint a nők, és vizsgálatunkban a testi erőszak volt a fó etiológiai faktor az angulustöröttek csoportjában, míg a második leggyakoribb ok a condylustöröttekében [43]. A condylustörés-csoportban szintén férfidominancia látható, de itt a nők szignifikánsan gyakrabban érintettek, mint az angulustörés-csoportban. Ez összefügghet azzal, hogy a condylustöröttek csoportjában a fó etiológiai faktor az esés volt, ami a nők körében gyakoribb lehet. Azok a tanulmányok, amelyekben a közlekedési baleset volt a fó etiológiai faktor, szintén férfidominanciáról számoltak be $[20,33]$.

Vizsgálatunk egy klinika adatait vizsgálta. Mivel az etiológia nagyban befolyásolja a törést okozó erő jellemzőit, és az etiológiai faktorok megoszlása földrajzi régiónként változik, több központú adatgyújtés megfelelőbb lenne, 
hogy lehetővé váljon az etiológiai tényezők kiegyensúlyozottabb elemzése, attól függetlenül, hogy mi is volt a domináns faktor. További, nagy esetszámú vizsgálat szükséges az occlusiós megtámasztás mandibulatörést befolyásoló szerepének elemzésére. A nagy esetszám feltehetően lehetővé tenné a különböző etiológiájú törések és az occlusiós megtámasztás közti kapcsolat kimutatását is.

\section{Következtetés}

A molaris területi occlusiós megtámasztás jelenléte szignifikánsan összefüggött az angulustörés kialakulásával. A bölcsességfogak jelenléte szignifikánsan ( 8,1-szeresre) növelte az angulustörés rizikóját. Idősebb betegekben, ha a molaris tájékon hiányzik az occlusiós megtámasztás, vagy az alsó bölcsességfog hiányzik, akkor a condylustörés rizikója jelentősen fokozódik. Az occlusio minőségére kisebb hatásunk lehet, de a panaszmentes bölcsességfogak eltávolításával nagymértékben meghatározhatjuk a traumának kitett betegcsoport állkapocstörési mintázatát.

Anyagi támogatás: A közlemény megírása anyagi támogatásban nem részesült.

Szerzői munkamegosztás: S. B.: A kutatás megtervezése, adatgyűjtés, a cikk megírása. J. K.: Adatgyüjtés. T. Á.: Statisztikai elemzés. Sz. J.: A kutatási terv meghatározása, a cikk megírása. A közlemény végleges változatát mind a négy szerző elolvasta és jóváhagyta.

Érdekeltségek: A szerzőknek nincsenek érdekeltségeik.

\section{Köszönetnyilvánítás}

Köszönetünket fejezzük ki Jeges Sára tanárnőnek a statisztikai kérdésekben nyújtott segítségéért, valamint a szájsebészeti ambulancia munkatársainak a támogatásukért.

\section{Irodalom}

[1] Hogg NJ, Stewart TC, Armstrong JE, et al. Epidemiology of maxillofacial injuries at trauma hospitals in Ontario, Canada, between 1992 and 1997. J Trauma 2000; 49: 425-432.

[2] Zhou H, Lv K, Yang R, et al. Mechanics in the production of mandibular fractures: a clinical retrospective case-control study. PLoS ONE 2016; 11: e0149553.

[3] Ellis E 3rd. Advances in maxillofacial trauma surgery. In: Fonseca RJ, Walker RV. (eds.) Oral and maxillofacial trauma. 2nd edn. W.B. Saunders Company, Philadelphia, PA, 1997; pp. 308-363.

[4] Zhou HH, Liu Q, Cheng G, et al. Aetiology, pattern and treatment of mandibular condylar fractures in 549 patients: a 22 -year retrospective study. J Craniomaxillofac Surg. 2013; 41: 34-41.

[5] Boffano P, Roccia F. Bilateral mandibular angle fractures: clinical considerations. J Craniofac Surg. 2010; 21: 328-331.

[6] Sawazaki R, Junior SM, Asprino L, et al. Incidence and patterns of mandibular condyle fractures. J Oral Maxillofac Surg. 2010; 68: $1252-1259$
[7] Lee JT, Dodson TB. The effect of mandibular third molar presence and position on the risk of an angle fracture. J Oral Maxillofac Surg. 2000; 58: 394-399.

[8] Cornelius CP, Audigé L, Kunz C, et al. The comprehensive AOCMF classification system: mandible fractures - level 2 tutorial. Craniomaxillofac Trauma Reconstr. 2014; 7(Suppl 1): S15S30.

[9] Mah DH, Kim SG, Moon SY, et al. Relationship between mandibular condyle and angle fractures and the presence of mandibular third molars. J Korean Assoc Oral Maxillofac Surg. 2015; 41: 3-10.

[10] Armond AC, Martins CC, Glória JC, et al. Influence of third molars in mandibular fractures. Part 1: Mandibular angle - a meta-analysis. Int J Oral Maxillofac Surg. 2017; 46: 716-729.

[11] Safdar N, Meechan JG. Relationship between fractures of the mandibular angle and the presence and state of eruption of the lower third molar. Oral Surg Oral Med Oral Pathol Oral Radiol Endod. 1995; 79: 680-684.

[12] Armond AC, Martins CC, Glória JC, et al. Influence of third molars in mandibular fractures. Part 2: Mandibular condyle - a meta-analysis. Int J Oral Maxillofac Surg. 2017; 46: 730-739.

[13] Huelke DF, Burdi AR, Eyman CE. Association between mandibular fractures and site of trauma, dentition, and age. J Oral Surg Anesth Hosp Dent Serv. 1962; 20: 478-481.

[14] Zhu SJ, Choi BH, Kim HJ, et al. Relationship between the presence of unerupted mandibular third molars and fractures of the mandibular condyle. Int J Oral Maxillofac Surg. 2005; 34: 382385.

[15] Rudderman RH, Mullen RL. Biomechanics of the facial skeleton. Clin Plast Surg. 1992; 19: 11-29.

[16] Bezerra TP, Silva Junior FI, Scarparo HC, et al. Do erupted third molars weaken the mandibular angle after trauma to the chin region? A 3D finite element study. Int J Oral Maxillofac Surg. 2013; 42: 474-480.

[17] Soós B, Janovics K, Tóth Á, et al. Association between third molar impaction status and angle or condylar fractures of the mandible - a retrospective analysis. J Oral Maxillofac Surg. 2020 March 6. Doi: 10.1016/j.joms.2020.02.005. [Online ahead of print]

[18] Iida S, Nomura K, Okura M, et al. Influence of the incompletely erupted lower third molar on mandibular angle and condylar fractures. J Trauma 2004; 57: 613-617.

[19] Iida S, Hassfeld S, Reuther T, et al. Relationship between the risk of mandibular angle fractures and the status of incompletely erupted mandibular third molars. J Craniomaxillofac Surg. 2005; 33: $158-163$.

[20] Mehra A, Anehosur V, Kumar N. Impacted mandibular third molars and their influence on mandibular angle and condyle fractures. Craniomaxillofac Trauma Reconstr. 2019; 12: 291-300.

[21] Reitzik M, Lownie JF, Cleaton-Jones P, et al. Experimental fractures of monkey mandibles. Int J Oral Surg. 1978; 7: 100-103.

[22] Pell GJ, Gregory GT. Impacted mandibular third molars, classification and modified technique for removal. Dent Digest. 1933; 39: 330-337.

[23] Choi BJ, Park S, Lee DW, et al. Effect of lower third molars on the incidence of mandibular angle and condylar fractures. J Craniofac Surg. 2011; 22: 1521-1525.

[24] Winter GB. Principles of exodontia as applied to the impacted mandibular third molar. American Medical Book Company, St. Louis, MO, 1926; pp. 127-131.

[25] Laughlin RM, Block MS, Wilk R, et al. Resorbable plates for the fixation of mandibular fractures: a prospective study. J Oral Maxillofac Surg. 2007; 65: 89-96.

[26] Ulbrich N, Ettl T, Waiss W, et al. The influence of third molars in the line of mandibular angle fractures on wound and bone healing. Clin Oral Investig. 2016; 20: 1297-1302.

[27] McNamara Z, Findlay G, O'Rourke P, et al. Removal versus retention of asymptomatic third molars in mandibular angle frac- 
tures: a randomized controlled trial. Int J Oral Maxillofac Surg. 2016; 45: 571-574.

[28] Ellis E 3rd, Moos KF, el-Attar A. Ten years of mandibular fractures: an analysis of 2,137 cases. Oral Surg Oral Med Oral Pathol. 1985; 59: 120-129.

[29] Xu S, Huang JJ, Xiong Y, et al. How is third molar status associated with the occurrence of mandibular angle and condyle fractures? J Oral Maxillofac Surg. 2017; 75: 1476.el-1476 el5.

[30] Naghipur S, Shah A, Elgazzar RF. Does the presence or position of lower third molars alter the risk of mandibular angle or condylar fractures? J Oral Maxillofac Surg. 2014; 72: 1766-1772.

[31] Dodson TB, Susarla SM. Impacted wisdom teeth. BMJ Clin Evid. 2014; 2014: 1302 .

[32] Shoshani-Dror D, Shilo D, Ginini JG, et al. Controversy regarding the need for prophylactic removal of impacted third molars: an overview. Quintessence Int. 2018; 49: 653-662.

[33] Samieirad S, Eshghpour M, Dashti R, et al. Correlation between lower third molar impaction types and mandibular angle and condylar fractures: a retrospective study. J Oral Maxillofac Surg. 2019; 77: 556-564

[34] Hasegawa T, Sadakane H, Kobayashi M, et al. A multi-centre retrospective study of mandibular fractures: do occlusal support and the mandibular third molar affect mandibular angle and condylar fractures? Int J Oral Maxillofac Surg. 2016; 45: 10951099

[35] Kromer H. Closed and open reduction of condylar fractures. D Record 1953; 73: 569-571.

[36] Hayward JR. Fractures involving the mandibular condyle; a posttreatment survey of 120 cases. J Oral Surg (Chic). 1947; 5: 4573.

[37] Ribeiro-Junior PD, Senko RA, Momesso NR, et al. Occlusal instability results in increased complication rates after treatment of mandibular fractures. Oral Maxillofac Surg. 2020 Feb 19. Doi: 10.1016/j.joms.2020.02.013. [Online ahead of print]

[38] Kelly D, Harrigan W. A survey of facial fractures: Bellevue Hospital, 1948-1974. J Oral Surg. 1975; 33: 146-149.

[39] Szalma J, Lempel E, Jeges S, et al. Digital versus conventional panoramic radiography in predicting inferior alveolar nerve injury after mandibular third molar removal. J Craniofac Surg. 2012; 23: el55-el58.

[40] Antic S, Milicic B, Jelovac DB, et al. Impact of the lower third molar and injury mechanism on the risk of mandibular angle and condylar fractures. Dent Traumatol. 2016; 32: 286-295.
[41] Chrcanovic BR, Abreu MH, Freire-Maia B, et al. 1,454 man dibular fractures: A 3-year study in a hospital in Belo Horizonte, Brazil. J Craniomaxillofac Surg. 2012; 40: 116-123.

[42] Tiwari A, Lata J, Mishra M. Influence of the impacted mandibular third molars on fractures of the mandibular angle and condyle - a prospective clinical study. J Oral Biol Craniofac Res. 2016; 6: 227-230.

[43] Duan DH, Zhang Y. Does the presence of mandibular third molars increase the risk of angle fracture and simultaneously decrease the risk of condylar fracture? Int J Oral Maxillofac Surg. 2008; 37: 25-28.

[44] Inaoka SD, Carneiro SC, Vasconcelos BC, et al. Relationship between mandibular fracture and impacted lower third molar. Med Oral Patol Oral Cir Bucal 2009; 14: E349-E354.

[45] Ruela WS, de Almeida VL, Lima-Rivera LM, et al. Does an association exist between the presence of lower third molar and mandibular angle fractures? A meta-analysis. J Oral Maxillofac Surg. 2018; 76: 34-45.

[46] Giovacchini F, Paradiso D, Bensi C, et al. Association between third molar and mandibular angle fracture: a systematic review and meta-analysis. J Craniomaxillofac Surg. 2018; 46: 558-565.

[47] Szalma J, Lempel E, Jeges S, et al. The prognostic value of panoramic radiography of inferior alveolar nerve damage after mandibular third molar removal: retrospective study of 400 cases. Oral Surg Oral Med Oral Pathol Oral Radiol Endod. 2010; 109: 294-302.

[48] Guerrero ME, Botetano R, Beltran J, et al. Can preoperative imaging help to predict postoperative outcome after wisdom tooth removal? A randomized controlled trial using panoramic radiography versus cone-beam CT. Clin Oral Investig. 2014; 18: 335342.

[49] Antic S, Saveljic I, Nikolic D, et al. Does the presence of an unerupted lower third molar influence the risk of mandibular angle and condylar fractures? Int J Oral Maxillofac Surg. 2016; 45: 588-592.

[50] Szalma J, Lempel E. Protecting the inferior alveolar nerve: coronectomy of lower third molars. Review. [A nervus alveolaris inferior védelmében: alsó bölcsességfogak coronectomiája. Irodalmi áttekintés.] Orv Hetil. 2017; 158: 1787-1793. [Hungarian]

(Soós Balázs dr., Pécs, Dischka u. 5., 7621 e-mail: soosbalazsdr@gmail.com)

\title{
Felnőtt háziorvosi praxis Szegeden eladó
}

\section{Szeged belvárosában felnőtt háziorvosi praxis praxisjoga eladó, területi ellátási kötelezettséggel.}

\author{
Érdeklödni lehet: 06 30/383-5657
}

A cikk a Creative Commons Attribution 4.0 International License (https://creativecommons.org/licenses/by/4.0/) feltételei szerint publikált Open Access közlemény, melynek szellemében a cikk bármilyen médiumban szabadon felhasználható, megosztható és újraközölhető, feltéve, hogy az eredeti szerző és a közlés helye, illetve a CC License linkje és az esetlegesen végrehajtott módosítások feltüntetésre kerülnek. (SID_1) 